\title{
Pelatihan Pembuatan Preparat Segar Biologi Untuk Meningkatkan Keterampilan Guru dan Siswa di SMA Negeri 1 Argamakmur, Kabupaten Bengkulu Utara
}

\author{
Risky Hadi Wibowo ${ }^{1 *}$, Sipriyadi ${ }^{2}$, Fatimatuzzahra ${ }^{3}$, Reza Wahyuni ${ }^{4}$, \\ Redo Setiawan ${ }^{5}$, Annisa Prastika ${ }^{6}$, Rizawati ${ }^{7}$ \\ ${ }^{123456}$ Jurusan Biologi, Fakultas Matematika dan Ilmu Pengetahuan Alam, \\ Universitas Bengkulu \\ ${ }^{7}$ SMAN 1 Arga Makmur, Bengkulu Utara \\ E-mail: rhwibowo@unib.ac.id
}

Article History:

Received: Oktober 2021

Revised: November 2021

Accepted: November 2021

Available online:

Desember 2021

Keywords: Biologi, Guru,Laboratorium, Preparat Segar, Siswa
Abstract: Biologi merupakan cabang ilmu sains yang mempelajari tentang mahluk hidup baik secara mikroskopis hingga makroskopis seperti hewan, tumbuhan, jamur, bakteri, virus, manusia, dan protista. Untuk meningkatkan mutu pengajaran di bidang biologi perlu peningkatan keterampilan dalam bekerja di laboratorium atau yang sering disebut dengan praktikum. Pelaksanaan kegiatan pengabdian kepada masyarakat pada pelatihan pembuatan preparat segar yang diikuti peserta sebanyak 20 siswa/i dan 5 orang guru SMA Negeri 1 Argamakmur, Bengkulu Utara diawali dengan tahap persiapan, kemudian sosialisasi pemberian materi pengabdian kepada pesertapengabdian dengan pengenalan dan manfaat pembuatan preparat, praktek pembuatan preparat segar yang menghasilkan 5 jenis preparat yang diamati di bawah mikroskop binokuler yaitu preparat eritrosit (darah merah) manusia, sel akar bawang, sel epitel mukosa pipi, sel bakteri dan hifa pada jamur tempe. Kegiatan pengabdian ini diharapkan dapat memberi pemahaman dan meningkatkan skill para guru biologi dan siswa-siswi dalam membuat preparat yang akan dimanfaatkan dalam proses belajar mengajar (KBM) pada kegiatan praktikum pelajaran biologi di Laboratorium. 


\section{Pendahuluan}

Peningkatan dari kualitas pendidikan di negara Indonesia terutama pendidikan pada bidang Ilmu Pengetahuan Alam (IPA) yang merupakan ilmu yang mendasari perkembangan sains dan teknologi, sehingga membuat pendidikan IPA menjadi sangat penting. Dalam upaya peningkatan mutu pendidikan perlu dilakukan berbagai macam upaya seperti pembaruan dan penambahan metode pembelajaran yang mudah dipahami bagi para siswa sehingga target yang akan dicapai berpeluang lebih besar tercapai (Saud, 2009). Salah satu mata pelajaran IPA yang perlu ditingkatkan mutu pengajarannya yaitu biologi yang merupakan ilmu yang mempelajari tentang mahluk hidup baik yang mikroskopis hingga makroskopis seperti hewan, tumbuhan, jamur, bakteri, virus, manusia, protista dan lain sebagainya. Ilmu biologi mempunyai beberapa cabang seperti mikrobiologi, fisiologi, bioteknologi dan yang penting juga yaitu histologi. Untuk meningkatkan mutu pengajaran di bidang biologi tidak cukup hanya dilakukan dengan memahami materi di ruang kelas, namun perlu didukung dengan kegiatan di lapangan dan di laboratorium atau yang sering disebut dengan praktikum (Puger, 2012).

SMAN 1 Argamakmur merupakan salah satu sekolah di Kabupaten Bengkulu Utara yang telah melaksanakan kegiatan praktikum, namun meskipun sudah tersedia mikroskop dan alat serta bahan praktikum, guru dan siswa belum dapat melaksanakan kegiatan praktikum pengamatan jaringan hewan ataupun tumbuhan secara optimal. Hal tersebut disebabkan karena kurang tersedianya sarana ataupun media untuk praktikum berupa preparat atau spesimen. Preparat merupakan bahan atau objek yang akan diamati menggunakan mikroskop. Ketidaktersediaan media preparat tersebut disebabkan preparat buatan pabrik memiliki harga yang relatif mahal dan tanaman yang digunakan untuk preparat belum tentu diketahui oleh siswa. solusi terbaik dalam upaya pemenuhan preparat yaitu dengan cara membuat sendiri.

Metode pembuatan preparat telah banyak mengalami perkembangan seiring dengan berkembangannya peralatan alat bantu mikroskopis, metode pewarnaan dan peningkatan pemahaman tentang sifat dan perilaku sel atau jaringan. Jaringan dan sel harus dipertahankan dalam keadaan basah pada larutan garam, agar tidak mengalami perubahan dan untuk mempertahankan komponen jaringan ataupun sel tersebut melalui proses fiksasi (Samiyarsih, et al., 2013). 
Guru memegang peranan penting dalam peningkatan kualitas siswa dalam belajar biologi dan guru harus benar-benar, memikirkan, memperhatikan dan sekaligus merencakan proses belajar mengajar secara inovatif, kreatif dan berpusat pada peserta didik dengan mengembangkan pendekatan keterampilan proses Sains. Para staf guru biologi umumnya masih keterbatasan keterampilan dalam pembuatan preparat awetan di laboratorium. Selain itu juga sebagian dari sekolah mereka masih terbatasnya sarana dan prasarana laboratorium, menyebabkan setiap siswa tidak mendapatkan kesempatan belajar untuk mengadakan eksperimen (Mertha et al., 2019)

Mengingat banyaknya metode pembuatan preparat dalam biologi yang semakin berkembang, maka dalam kegiatan pengabdian kepada masyarakat (PPM) ini akan diberikan pelatihan pembuatan preparat segar biologi dengan metode standar yang perlu diketahui sebagai dasar untuk pengembangan selanjutnya seperti pada pembuatan preparat sel darah dengan metode smear (Salnus, 2020), dan pembuatan preparat mikrob melalui proses fiksasi (Lay, 1994). Tujuan dari kegiatan PPM ini adalah melatih guru dan para siswa/siswi dalam pembuatan preparat segar biologi yang akan dimanfaatkan dalam proses belajar mengajar (praktikum) di laboratorium.

\section{Metode}

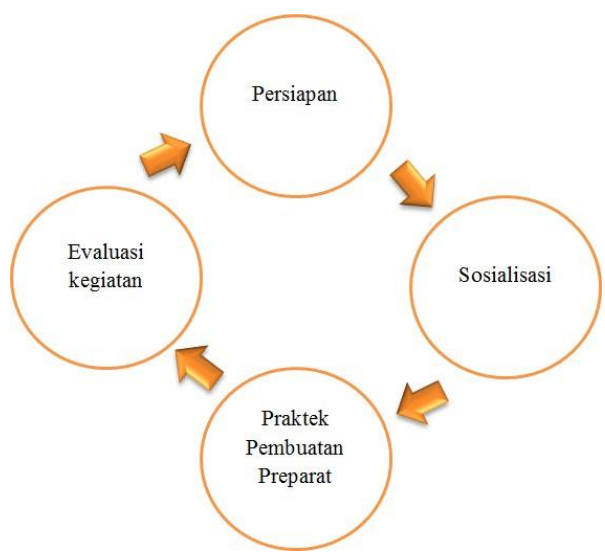

Gambar 1. Diagram pelaksanaan kegiatan PPM pelatihan pembuatan preparat 
Dharma Raflesia

Jurnal Ilmiah Pengembangan dan Penerapan IPTEKS

Vol. 19, No. 02, Desember, 2021, pp. 389 - 398

Kegiatan pengabdian mengenai pelatihan pembuatan preparat segar biologi untuk meningkatkan keterampilan guru dan siswa di SMA Negeri 1 Argamakmur, Bengkulu Utara, dilaksanakan pada hari Sabtu tanggal 9 Oktober 2021 yang dihadiri oleh 25 peserta. Beberapa tahapan pengabdian diawali dengan tahap persiapan yaitu koordinasi tim terlebih dahulu dengan pihak LPPM dan khalayak sasaran pengabdian yaitu siswa/i dan para guru biologi. Kemudian dilakukan pengurusan perizinan di SMA Negeri 1 Argamakmur, selanjutnya tahap sosialisasi dengan memberikan materi dari tim pengabdi mengenai teknik pembuatan preparat, cara mengamatinya di bawah mikroskop dan manfaat dilaksanakan kegiatan ini. Pada tahap praktek pembuatan preparat, para tim pengabdian memberi pengajaran dan praktek secara langsung kepada siswa dan guru SMA Negeri 1 Argamakmur, diikuti dengan para siswa/i dan guru yang ikut membuat preparat segar dari bahan yang tersedia dan diakhiri evaluasi kegiatan pengabdian serta foto bersama seluruh tim dan peserta pengabdian (Gambar 1).

Pembuatan preparat terdiri dari preparat tumbuhan, preparat hewan dan preparat mikrob. Pembuatan preparat tumbuhan dengan meletakkan kaca benda yang telah ditetesi air diatasnya, kemudian disayat tumbuhan segar dan diletakkan diatas kaca benda, ditutup dengan kaca penutup dan dilakukan pengamatan menggunakan mikroskop.

Pada pengamatan sel hewan pada obejek eritrosit, pengambilan darah dari ujung jari yang ditusuk dengan jarum franke yang telah disterilkan dengan alkohol $70 \%$, diusap ujung jari dengan alkohol. Darah diteteskan langsung pada gelas objek pada bagian sisi kanan. Cover glass ditempelkan dengan posisi miring pada bagian atas tetes darah kemudian tarik dengan arah menjauhi sisi kanan objek glass, sehingga tidak ada gelembung udara (Anjarwati et al., 2020). ada prosedur pembuatan preparat sel epitel rongga mulut yaitu kaca benda ditetesi dengan metilen blue kemudian diolesi dengan epitel rongga mulut yang telah diambil dari rongga mulut menggunakan tusuk gigi.

Teknik pembuatan preparat dengan objek isolat bakteri melalui proses fiksasi dilakukan dengan cara melewatkan preparat yang berisi isolat yang telah diberi setetes air dipanaskan diatas api untuk mematikan sel bakteri, pemberian zat warna seperti Kristal violet dan safranin yang digunakan untuk mengamati morfologi sel bakteri (Hadioetomo, 1993).

Pada pengamatan sel jamur dilakukan dengan cara kaca benda ditetsi dengan air, kemudian satu ose biakan jamur diambil dan dioleskan diatas kaca benda, dilanjutkan dengan menambahkan Lactophenol blue (Ristiari et 
Dharma Raflesia

Jurnal Ilmiah Pengembangan dan Penerapan IPTEKS

Vol. 19, No. 02, Desember, 2021, pp. 389 - 398

al., 2019).

Setiap pengamatan preparat dibawah mikroskop dilakukan dengan perbesaran rendah dan dilanjutkan dengan perbesaran tinggi. jika objek sudah terlihat, ditambahkan minyak imersi untuk memperjelas objek.

\section{Hasil}

Pada awal kegiatan pengabdian dimulai dengan permohonan izin kegiatan pengabdian kepada pihak sekolah sebagai tempat mitra sasaran diadakan acara pengabdian dengan melakukan pertemuan tim pengabdian dengan kepala sekolah dan wakil kepala sekolah bidang kurikulum SMA Negeri 1 Argamakmur. Permohonan izin ini disambut dengan baik oleh pihak sekolah untuk diadakan pengabdian sebagai ruang pembelajaran bagi para guru dan siswa-siswi.

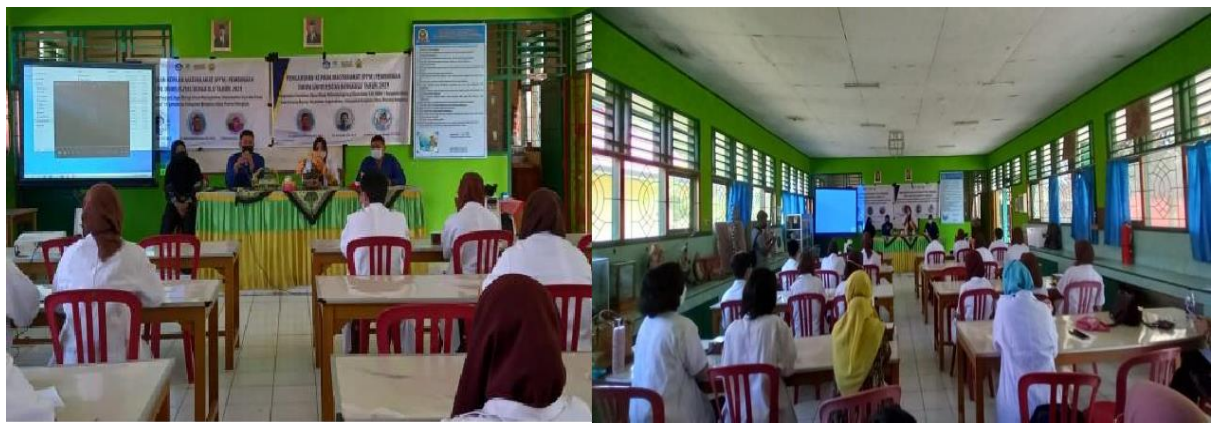

Gambar 2. Pemberian materi pengabdian berupa pelatihan pembuatan preparat segar kepada guru dan siswa-siswi SMAN 1 Argamakmur

Pada tahap selanjutnya, tim pengabdian memberikan sosialisasi mengenai pengertian preparat segar biologi, teknik pembuatan preparat, cara pengamatan preparat pada mikroskop cahaya binokuler, teknik pengambilan foto yang baik di bawah mikroskop dan manfaat dari belajar membuat preparat kepada para siswa dan guru di SMA Negeri 1 Argamakmur, Bengkulu Utara sebagai upaya untuk meningkatkan pemahaman dan keterampilan khususnya dalam bidang pembelajaran biologi di sekolah (Gambar 2).

Pada kegiatan pelatihan pembuatan preparat, para siswa dan guru sangat antusias masing-masing untuk membuat preparat segar. Preparat segar yang berhasil dibuat oleh para siswa/i dan guru sebanyak 5 jenis preparat segar dari sel darah manusia, sel epitel mukosa pipi, sel kulit bawang, sel 
bakteri dan hifa jamur pada tempe dengan perbesaran 40x, 100x, dan 1000x (Gambar 3). Preparat segar dibuat dengan meletakkan objek yang akan diamati ke atas kaca objek yang telah steril dibersihkan alkohol $70 \%$ kemudian ditutup oleh kaca penutup kemudian diamati pada mikroskop dengan perbesaran 40x, 100x dan 1000x, kemudian ditetesi dengan minyak imersi agar objek yang diamati terlihat jelas. Pengamatan pada preparat segar diamati dengan perbesaran kecil hingga perbesaran besar untuk mempermudah saat pengamatan preparat (Mertha et al., 2019).

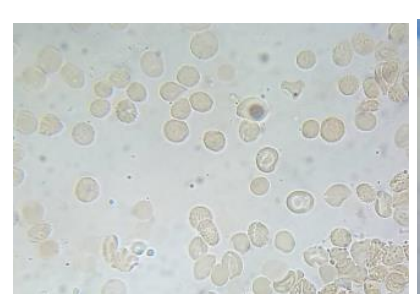

A

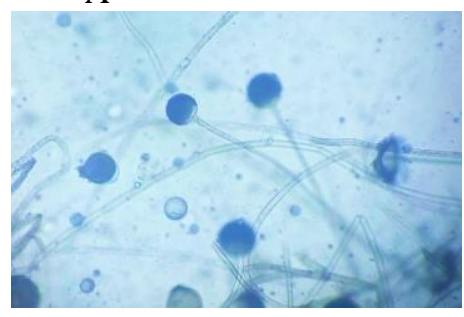

$\mathrm{D}$
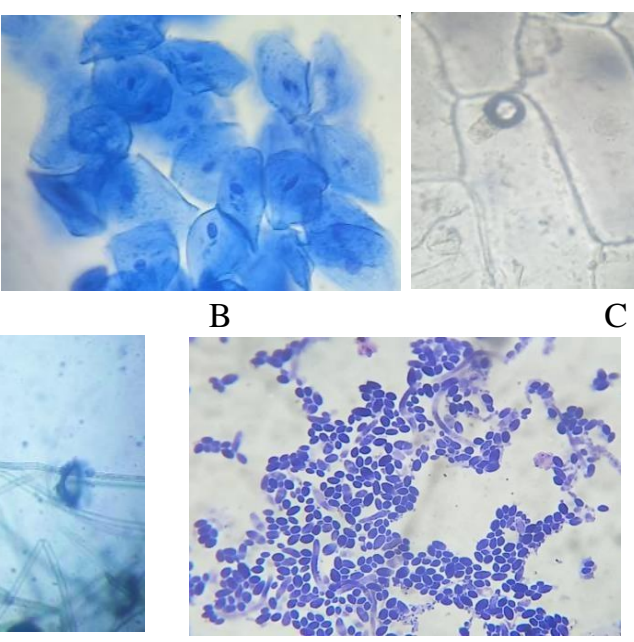

$\mathrm{E}$

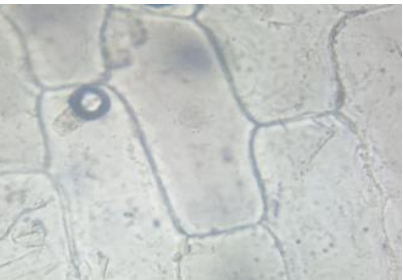

$\mathrm{C}$

Gambar 3. Hasil pembuatan preparat segar dari kegiatan PPM mengenai pembuatan preparat yaitu preparat eritrosit (A), preparat sel epitel mukosa pipih (B) preparat sel tumbuhan (C), dan preparat hifa jamur (D) preparat sel bakteri (E) dengan perbesaran 1000x

Berdasarkan Gambar 3, Hasil pembuatan preparat segar terdiri dari preparat eritrosit tampak bentuk sel bulat tanpa adanya inti sel, pada sel epitel mukosa pipih terlihat bentuk sel yang tidak teratur namun tampak jelas pada inti sel, pada preparat sel tumbuhan dari objek sayatan bawang merah memiliki bentuk sel persegi dan dinding sel. Perbedaan pada sel tumbuhan dan sel hewan dari bentuk sel dan organel penyusun selnya (Huda, 2015). Pengamatan preparat dari objek tempe didapatkan jamur Rhizopus sp. yang memiliki spora, sporangium dan sporangiofor. Menurut Sine (2018), jamur yang berperan dalam fermentasi tempe berasal dari kelompok Rhizopus yang memiliki spora yang berada di dalam sporangium,Pada preparat sel 
Dharma Raflesia

Jurnal Ilmiah Pengembangan dan Penerapan IPTEKS

Vol. 19, No. 02, Desember, 2021, pp. 389 - 398

bakteri Lactobacillus didapatkan dari objek minuman fermentasi yang termasuk dalam bakteri Gram positif dengan sel berbentuk basil.

Preparat awetan biologi yang bersifat mikroskopis, seperti preparat jaringan tumbuhan, smear darah, jaringan hewan, berbagai mikroorganisme bakteri, jamur, alga melalu proses fiksasi dan pewarnaan Gram. Pembuatan awetan biologi yang mikroskopis membutuhkan tahapan pembuatan yang prosedural, sehingga dapat menghasilkan preparat yang berkualitas dan dapat digunakan dalam jangka waktu yang lebih lama (Samiyarsih et al., 2019).

\section{Pembahasan}

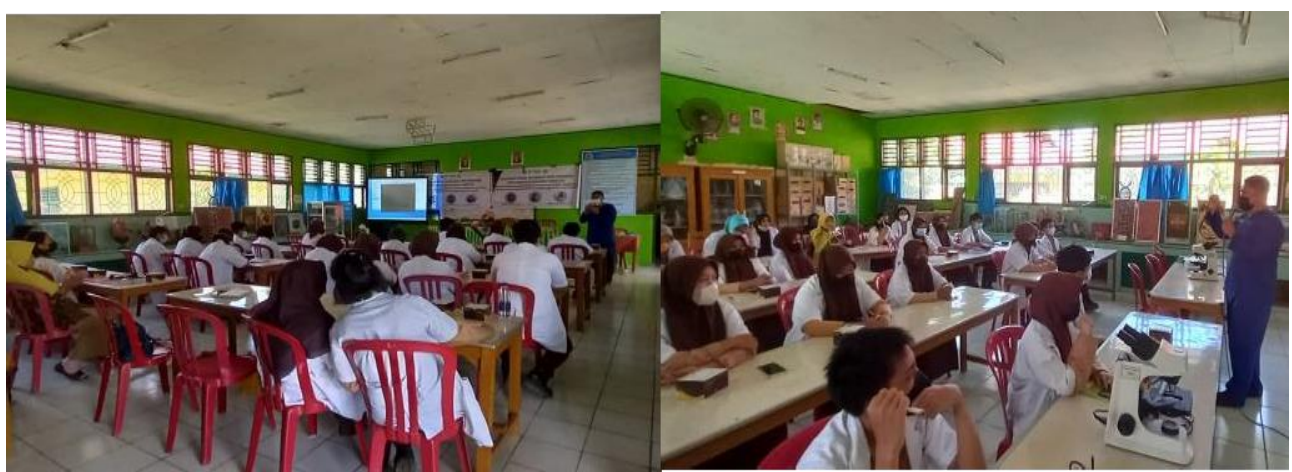

Gambar 4. Praktek pembuatan preparat segar oleh tim pengabdian kepada peserta pengabdian

Praktek pembuatan preparat segar dilakukan oleh tim pengabdian pada para staf guru dan siswa-siswi dengan mempraktekkan secara langsung teknik pembuatan preparat segar lalu dilanjutkan dengan pengamatan preparat di bawah mikroskop (Gambar 4). Para tim pengabdian memberikan pelatihan kepada peserta pengabdian secara langsung dalam membuat preparat. Setelah pembuatan preparat, tim pengabdian memberi tahu cara mengamati preparat menggunakan mikroskop secara tepat dan benar, hal ini mampu menambah keterampilan siswa dan guru dalam bekerja di laboratorium saat praktikum pada bidang pelajaran biologi. Pelatihan serta pembuatan secara langsung kepada peserta pengabdian ialah bentuk demontrasi aktivitas pengabdianmenggunakan melibatkan peserta didik dan guru mempraktekkan secara langsung pembuatan serta pengamatan preparat (Abidin et al., 2014).

Faktor yang menunjang kegiatan praktikum materi pengamatan mikroskopis bukan hanya dari mikroskop dan alat serta bahan, melainkan tersedianya preparat yang dapat dijadikan sebagai objek pengamatan. Maka 
Dharma Raflesia

Jurnal Ilmiah Pengembangan dan Penerapan IPTEKS

Vol. 19, No. 02, Desember, 2021, pp. 389 - 398

dari itu guru belum dapat melaksanakan kegiatan praktikum pengamatan jaringan atau sel tanaman. Hal tersebut disebabkan karena tidak tersedianya media untuk praktikum berupa preparat atau spesimen. Dalam pelaksanannya upaya peningkatan pendidikan biologi tidak lepas dari kegiatan dilaboratorium, namun selain SDM, sarana dan prasarana juga menjadi hal yang sangat penting salah satunya yaitu preparat biologi. Kurangnya keterampilan dan pengetahuan membuat preparat, maka tim pengabdian menggunakan bahan dan metode yang lebih sederhana, teknik pembuatan preparat segar dari tumbuhan yaitu tanaman yang akan diamati pada bagian daun atau batang disayat tipis secara melintang dan membujur menggunakan silet, kemudian sayatan tipis tersebut diberi air pada kaca preparat sel tumbuhan dalam Gambar 3, kemudian ditutup oleh kaca penutup untukdapat diamati (Achmad et al., 2013).

Keterampilan membuat preparat adalah pengalaman berharga yang diperoleh para guru dan siswa disekolah dalam bekerja di laboratorium pada pelajaran biologi. Selain itu keterampilan pengamatan menggunakan mikroskop akan terasah. Kegiatan pengabdian ini memiliki relevansi dengan kebutuhan guru saat mengajar di laboratorium. Selain penguasaan materi, guru biologi juga harus mampu mengelola laboratorium (Munkashi et al., 2018).

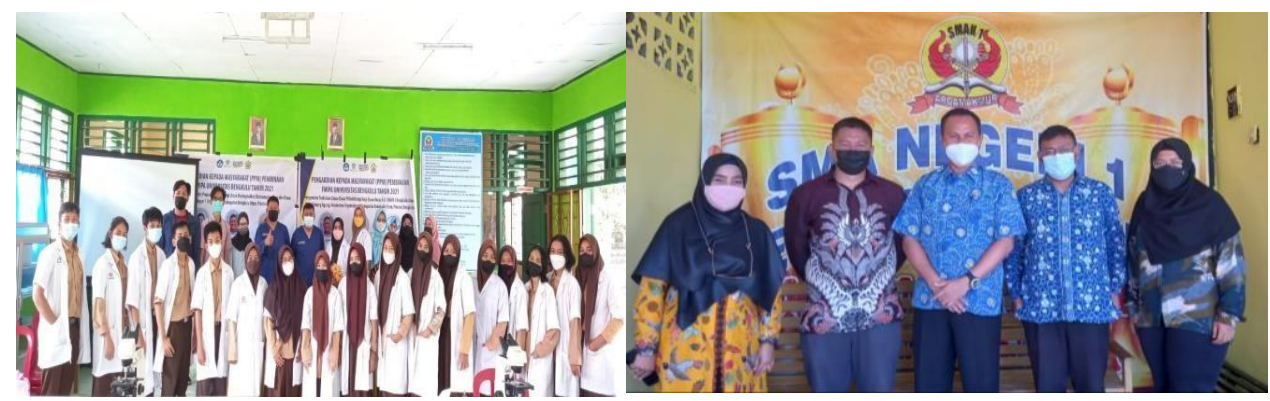

Gambar 5. Foto bersama seluruh tim dan peserta pengabdian yang terdiri dari para guru dan siswa serta kepala sekolah dan wakil kepala sekolah SMA Negeri 1 Argamakmur

Diakhir acara pengabdian, para peserta pengabdian dan tim pengabdian melakukan sesi foto bersama sebagai bentuk dokumentasi acara pengabdian pelatihan pembuatan preparat segar biologi (Gambar 5). Acara pengabdian ini diharapkan para peserta pengabdian yaitu para guru dan siswa-siswi mampu mengetahui preparat dan memahami pembuatan preparat segar yang akan dimanfaatkan dalam proses belajar mengajar (praktikum) di Laboratorium. Kegiatan pengabdian sangat bermanfaat dalam menanbah 
Dharma Raflesia

Jurnal Ilmiah Pengembangan dan Penerapan IPTEKS

Vol. 19, No. 02, Desember, 2021, pp. 389 - 398

pengetahuan siswa dan guru melakukan penelitian atau pembelajaran di Laboratorium.

\section{Kesimpulan}

Kegiatan pengabdian kepada masyarakat mengenai pelatihan pembuatan preparat segar biologi diawali dengan sosialisasi pemberian materi pengabdian dengan pengenalan dan manfaat pembuatan preparat, praktek pembuatan preparat segar biologi seperti preparat eritrosit, sel tumbuhan, sel epitel mukosa, sel bakteri dan hifa pada jamur cara pengamatan preparat dimikroskop. Kegiatan pengabdian diharapkan para guru biologi dan siswa-siswi SMA Negeri 1 Argamakmur, Bengkulu Utara mampu memahami pembuatan dan manfaat preparat serta meningkatkan keterampilan bekerja dalam pembuatan dan pengamatan preparat segar biologi yang akan dimanfaatkan dalam proses belajar mengajar pada kegiatan praktikum pelajaran biologi di Laboratorium.

\section{Pengakuan}

Tim pengabdian mengucapkan terimakasih kepada Fakultas Matematika dan Ilmu Pengetahuan Alam dan Lembaga Penelitian dan Pengabdian Kepada Masyarakat (LPPM) Universitas Bengkulu melalui Hibah Pengabdian Pembinaan FMIPA UNIB 2021 dengan nomor kontrak: $2362 / \mathrm{UN} 30.12 / \mathrm{HK} / 2021$ tanggal 21 Juli 2021 atas nama Risky hadi Wibowo, dan pihak Sekolah SMA Negeri 1 Argamakmur, Bengkulu Utara yang telah memberikan izin kegiatan ini. serta seluruh peserta dan pihak pengabdian yang telah membantu menyukseskan kegiatan pengabdian hingga akhir acara pengabdian.

\section{Daftar Referensi}

Abidin, A.Z., Budiono,J.K. \& Isnawati. (2014). Pemanfaatan Filtrat Kulit Buah Syzygium cumini Sebagai Pewarna Alternatif Preparat Mitosis. Makalah Seminar Nasional Dan Workshop Biologi. Jurusan Biologi F- MIPA Universitas Negeri Surabaya 18-19 Oktober 2014.

Achmad, S.N.N., Budiono, J.D. \& Pratiwi, P.R. (2013). The Development of Plant Tissue Preparation Media using Alternative Dye of Henna Leaves (Lausonia inermis) Filtrate. Bioedu, 2(1) : 56-58.

Anjarwati, S., Wardany, K., \& Yanti, F. A. (2020). Lokakarya dan pelatihan pembuatan preparat biologi bagi guru-guru SMA di Lampung Timur. Sasambo: Jurnal Abdimas (Journal of Community Service), 2(2). 57-63.

Hadiotomo. RS. (1993). Mikrobiologi Dasar Dalam Praktek. Jakarta: Gramedia. pp. 47. 
Dharma Raflesia

Jurnal Ilmiah Pengembangan dan Penerapan IPTEKS

Vol. 19, No. 02, Desember, 2021, pp. 389 - 398

Huda, S. N., \& Kusumo, D. A. (2015). Alat Bantu Ajar Pengenalan Sel Hewan dan Tumbuhan. Prosiding SENTIA 2015.

Puger, I.G.N. (2012). Pengembangan Program Mengenai Aplikasi Metode Pembelajaran Kooperatif Model Jigsaw alam Meningkatkan Prestasi Belajar Biologi Siswa Sekolah Menengah Pertama (SMP). Widyatech Jurnal Sains dan Teknologi, 11(1):134-146.

Lay, B. (1994). Analisis Mikrob di Laboratorium. Jakarta: PT. Raja Grafika Persada.

Mertha, I. G., Al Idrus, A., Bahri, S., Sedijani, P., \& Rasmi, D. A. C. (2019). Pelatihan Pembuatan Preparat Squash jung Akar Untuk Pengamatan Kromosom Pada Guru-Guru Biologi Di Kota Mataram. Jurnal Pendidikan dan Pengabdian Masyarakat, 2(4).

Munkashi, G. A., Yolida, B., \& Achmad, A. (2017). Analisis pelaksanaan praktikum dan permasalahannya pada materi organisasi kehidupan di SMP. Jurnal Universitas Lampung, (1), 1-67.

Ristiari, N. P. N., Julyasih, K. S. M., \& Suryanti, I. A. P. (2019). Isolasi Dan Identifikasi Jamur Mikroskopis Pada Rizosfer Tanaman Jeruk Siam (Citrus nobilis Lour.) Di Kecamatan Kintamani, Bali. Jurnal Pendidikan Biologi undiksha, 6(1), 10-19.

Saud, Udin. (2009). Pengembangan Profesi Guru. Bandung: Alfabeta.

Samiyarsih, S., Herawati, W. \& Juwarno. (2013). Pelatihan Pembuatan Preparat Tumbuhan sebagai Sarana Peningkatan Proses Pembelajaran bagi Guru dan Siswa SMA Negeri 1 Purwokerto. Laporan Kegiatan Pengabdian kepada Masyarakat, Fakultas Biologi Unsoed.

Samiyarsih, S. (2019). Pelatihan Pembuatan Preparat Mikroskopis Tumbuhan Sebagai Sarana Peningkatan Program Pembelajaran Siswa SMP Negeri 1 Purwokerto. Prosiding, 8(1).

Salnus, S., \& Arwie, D. (2020). Ekstrak Antosianin Dari Ubi Ungu (Ipomoea Batatas L.) Sebagai Pewarna Alami pada Sediaan Apusan Darah Tepi. Jurnal Media Analis Kesehatan, 11(2), 96-103.

Sine, Y., \& Soetarto, E. S. (2018). Isolasi dan identifikasi Kapang Rhizopus pada Tempe Gude (Cajanus cajan L.). Savana Cendana, 3(4), 67-68. 